\title{
Calcium Cation
}

National Cancer Institute

\section{Source}

National Cancer Institute. Calcium Cation. NCI Thesaurus. Code C61660.

The metabolically-active portion of calcium, not bound to proteins, circulating in the blood. 